\title{
Narrative Technique as a Vehicle of Meaning in Shimmer Chinodya's Harvest of Thorns
}

\author{
Emmanuel Chibuzor Okereke \\ Correspondence: Emmanuel Chibuzor Okereke, National Examinations Council, Enugu State Office, Enugu, Nigeria. \\ E-mail: manmozo@yahoo.com
}

Received: Feb. 4, 2020

doi:10.5430/elr.v9n1p32

Accepted: Mar. 2, $2020 \quad$ Online Published: Mar. 3, 2020

URL: https://doi.org/10.5430/elr.v9n1p32

\begin{abstract}
This article is a critical examination of the select narrative techniques of Chinodya's Harvest of Thorns. The article focuses on characterization and diction. It attempts to examine and demonstrate the relevance of character, linguistic foregrounding, and unscripted performance, foregrounding imagery, flashback, juxtaposition and dialogue to the overall thematic concerns of the novel. It adopts formalist theory of literature to analyze the text. Themes of oppression, exploitation, corruption, resistance, disappointment, xenophobia, and social inequality are explored. While the article recommends that a person should be mindful of the kind of literature he or she patronizes, it concludes that literary technique is a vehicle through which the author's perceived themes are achieved.
\end{abstract}

Keywords: shimmer chinodya, technique, theme, character, oppression

\section{Introduction}

Shimmer Chinodya is one of the acclaimed Zimbabwean novelists. Born in 1957 in Gweru, Chinodya had his education at Goromonzi High School and the University of Zimbabwe, where he studied literature and education. Among his writings are Harvest of Thorns (1989), Child of War (published under the name of B. Chirasha in 1985), Farai's Girls (1984) and Dew in the Morning (1982). His novel, Harvest of Thorns (1989), won the 1990 Commonwealth Writers Prize for African Region. The novel, Harvest of Thorns, is a fictional representation of Rhodesia (now Zimbabwe) from colonial era to independence dispensation. The narrative is about the august visit of a few white men to the black people of Zimbabwe. The foreigners pretended to be good as their Rhodesian (Zimbabwean) hosts welcomed them. Unfortunately, the foreigners became dominant and turned oppressive and exploitative to the African people. The foreigner's despoilment and enslavement spark off violent agitation for self-determination in Zimbabwe by guerrilla warriors-youths. According to Jephias Andrew Dzimbanhete, "the white minority regime unleashed indiscriminate violence against the civilian population", with the intention to gather "information about the freedom fighters and punish the rural population for cooperating with the liberation fighters". Dzimbanhete maintained that the tactics of the white minority regime did not produce the desired result because "the liberation forces used violence against members of the rural population who collaborated with the Rhodesian regime and security forces" (2019, p.1). The consequences of the war include losses of lives on both sides of the white minority people and the black populace. They also include internal conflict between the guerrilla armies (ZANLA and ZIPRA), intolerance of disagreement, hunger, rape, rough punishment, including beating and execution of both people within the army and of the civilian population. The title of the novel is in itself symptomatic of the failed expectations of the guerrillas who fought for the actualization of independence in Zimbabwe. The freedom fighters, after winning independence, reap poverty, retrogression, abandonment and foreign hegemony, instead of good governance, employment, better housing and land repossession.

Even though the above mentioned historical events are depicted in Shimmer Chinodya's novel, Harvest of Thorns, the concern of this article is not to investigate the historical events in the novel, but to examine the literary techniques used to realize the thematic concerns of the novel.

\section{Literature Review}

On the blurb of the Heinemann International Literature and Textbooks edition of Harvest of Thorns (1990), Dorris Lessing observes that "Harvest of Thorns brilliantly pictures the transition between the old white dominated Southern Rhodesia, through the Bush War, to the new black regime". Staunton (1997) points out that Chinodya's Harvest of Thorns is an anti-colonial novel. Looking at the novel, and the novel, Pawns, by Charles Samupindi, 
Staunton (1997, p.4) comments that both Chinodya's Harvest of Thorns and Samupindi's Pawns "look at the reason why people, even children, went to join the struggle. Beyond commitment and determination to bring down the colonial regime, there were other sometimes more immediate (the violence of the Rhodesian regime, or unemployment), more romantic (a consequence of the broadcasts from Radio Freedom)". Staunton (1997) maintains that "the relationship drawn by Chinodya in Harvest of Thorns between the farm-worker, Msindo, and the farm-owner, Baas Mellecker is a complex one [...] It is a relationship of unequal but of mutual dependence and familiarity which makes his role in Baas Mellecker's death at the hands of the guerrillas more poignant" (p.7). Whereas Staunton's contention is mainly on social disparity between white oppressors and the oppressed blacks, the argument of this article is that literary technique is a vehicle through which the author's perceived themes of oppression, exploitation, corruption, resistance, disappointment, xenophobia and social inequality are realized.

\section{Theoretical Framework}

In order to consider Chinodya's narrative technique as a vehicle of meaning in Harvest of Thorns, formalist approach to the study of literature will be employed. In his essay captioned "Technique as Discovery", Schorer (1966, p.141) argued that "technique is the means by which the writer's experience, which is his subject matter, compels him to attend to it; technique is the only means he has of discovering, exploring, developing his subject, of conveying its meaning, and finally, of evaluating it". The import of this is that the narrative technique determines to a large extent, the success or failure of a work of art. Literary elements or techniques in a work of art collaborate to form a unified total meaning, or what S. T. Coleridge calls 'organic unity'; and the critic's role is to examine these techniques in their interconnections, bearing in mind that the meaning is realized through them. Brooks (1963) opines that:

The primary concern of criticism is with the problem of unity... the kind of whole which the literary work forms or fails to form, and the relation of the various parts to each other in building up this whole (p.174).

In the same vein, Robert Penn Warren (as cited by Scott (1962)) avers that "poetry does not inhere in any particular element but depends upon the set of relationships, the structure, which we call the poem". What this implies to the Formalists is that the narrative form determines the content of a work of art. However, this position of the Formalists is opposed by literary Sociologists. In the view of the literary Sociologists and critics, the relationship between literature and society is inseparable. Vazquez (1973) puts it this way: "Art and society are thus necessarily connected; no art has been unaffected by social influence and no art has failed to influence society" (p.116).

Whereas this is the position of the literary Sociologists, the position of the Formalists and the New Critics of North America is that art is independent, and therefore does not have any bond with society. This is evident in the words of Yevgeny Basin cited in Ngara's Art and Ideology in the African Novel- art is an "autonomous, closed structure unconnected to the real world around it" (Ngara, 1985, p.3). The implication of this is that the Formalists and the New Critics are opposed to any form of historic, moral, psychological, and sociological explication of a work of literature. For them, literature must be interpreted from the angle of its literary elements, and not from the angle of the society from which it emerges. In this regards, Scott (1962, p.181) maintains that "the critic, then, examines these elements in their interconnections, assuming that the meaning is made up of matters of form (meter, image, diction, and so forth) and matters of content (tone, theme, and so forth) working not separately but together". Among the major contributors of formalistic approach to the study of literature are T.S. Eliot, William Empson, R.P. Blackmur, Allen Tate, John Crowe Ransom, and Charles Nnolim. Nnolim (1999) posits that "the African novelist uses sophisticated techniques to achieve his purposes" (p.7). Going by the positions of Brooks, Schorer, and Nnolim, it is contended that an author's perceived message(s) in a work of art is (are) achieved via the techniques employed by the author.

From the foregoing, this article is a critical examination of the select narrative techniques of Chinodya's Harvest of Thorns. The article focuses on the characterization and diction. It tries to examine and justify the significance of character, linguistic foregrounding, and unscripted performance, foregrounding imagery, flashback, juxtaposition and dialogue to the overall thematic concerns of the novel. While themes of oppression, exploitation, corruption, resistance, disappointment, xenophobia, and social inequality will be explored, the main contention of the article will be that literary technique is a vehicle through which these themes are achieved.

\section{Methodology}

This study is library research based. The study is executed using descriptive qualitative method. It adopts formalist theory of literature as its theoretical framework. It specifically uses the stance of formalists- Cleanth Brooks, Mark Schorer, and Charles E. Nnolim- to contend that an author's perceived theme(s) in a work of art is (are) 
accomplished through the techniques utilized by the author. The primary source of the data is the novel of Shimmer Chinodya. While an in-depth study of the primary text provided an analysis of the work, other related and relevant study materials- textbooks, journal articles and essays- were consulted in this research effort.

\section{Discussion}

\subsection{Characterization/Character as a Vehicle of Meaning}

Chinodya adopts expository and dramatic methods of characterization in Harvest of Thorns. The characters created in the novel are described or discussed either by the omniscient narrator or by a character; and the characters are seen in action. Chinodya's depiction of fictional characters appears to be a truthful representation of life in Zimbabwe. His characters are not too numerous to forget. They have meaningful interpersonal relationships with their different groups, and play meaningful roles in the world of the novel. The names they bear, the way they talk, the way they carry out their functions, show that they are created in the image of real human beings with real human strengths and frailties. An examination of the main characters in relation to their roles in the episode will be carried out to ascertain whether or not Chinodya has given them the required character qualities for fostering the themes of the novel.

In Harvest of Thorns characters representing the white minority ruling class and those representing the black working class are used to realize the themes of oppression and exploitation. Baas Mellecker, for instance, represents the white minority ruling class, the agents of oppression and exploitation, while Msindo represents the Zimbabwean working class. As a farmer, Mellecker uses his farming profession to dispossess the black people of Zimbabwe of their land and oppress and exploit them. The likes of Msindo are relegated to the role of a mere servant. Msindo who is portrayed as the farm foreman of Baas Mellecker (the white farmer) is unable to select from the only yearly bonus of a pair of trousers given to each farm worker by Mellecker, due to his extraordinary height. "The farm workers call him Rangwani, The Long One" (p.140) because he is too tall. His height symbolizes deprivation. "He can only wear sandals made out of car tyres, for lack of a right size shoe" (p.140). As a tireless worker who works "twenty-nine days of the month in the tobacco and potato fields", Msindo is only paid "twenty-seven dollars a month" (p.146), which shows that he belongs to the class of the exploited. His unnamed first wife who also works for Baas Mellecker unfortunately dies of tuberculosis worsened by farm work. It is indicated that she is wasted (p.141) because Mellecker fails to take her to hospital on time; and perhaps due to poverty she is unable to go to hospital by herself or be taken to hospital by her husband. This suggests that Mellecker treats his labourers unfairly and inhumanly. To further show that Msindo is a representation of the working class, the oppressed and exploited, it is demonstrated that out of his four sons, the first is "a tractor-driver on the farm" and he "earns twenty-two dollars a month, five dollars more than the other men, and Baas Mellecker has hinted he might be made deputy foreman on the farm" (p.141). "The second works on the neighboring farm, milking cows", while "the third son is a soldier in the Rhodesian army, and, at fifty-eight dollars a month" (p.141). Msindo has been advised to advise his son to resign from Ian Smith's army, but he declines because "he knows many other black men's sons are in the army too" (p.141). For Msindo, his third son will continue with Ian Smith's army because "it is the job somebody has to do - like cleaning public toilets and burying the corpses of bandiets who die in prisons" (pp.141-142). Besides, his son might be jobless if he resigns from the army.

Because of sanctions mines are closing down, and because white people are trickling out of the country and very few replacing them, the domestic jobs once readily available to blacks (cooks, nannies, garden boys) are no longer there (p.142).

For his last son, he hopes to arrange a job for him on the farm. This is because he fears that his last son who is in Grade Five at local primary school might not be lucky to get a place for Grade Six "since only a quarter of the black children in Grade Five are allowed to go on to Grade Six" (p.142). The deduction of this is that Rhodesian children are given education that will only make them good and loyal servants; education that will make them address the likes of Mellecker (the white farmer) as Baas, a corruption of the word 'Boss'. As Mellecker's farm foreman, it is demonstrated that Msindo

has been working on this farm forty years, since he was a boy and Baas Mellecker was a chubby little fellow riding a tricycle, frolicking under his mother's skirts round the farmhouse. This farm has been Msindo's life. He knows every square metre soil on it, every ditch. He cannot think of himself existing separate from it, without it. The soil clings to his sandals, his skin is bleached reddish with it, grass seeds mats his hair [...] He has grown so used to the farm that it is his farm, almost (p.144).

The manner in which Msindo works on the farm of Baas Mellecker (which as a matter of fact is part of his ancestral 
land grabbed by Cecil John Rhodes) reminds us of Ngotho working on the farm of Mr Howlands (a typical Kenyan settler) in Ngugi wa Thiong'o's Weep Not, Child. Ngotho, as a Gikuyu man who is dispossessed of his land, but who wants to eke out a living, works on the farm of Mr Howlands (the white farmer). It is said that Mr Howlands "loved to see Ngotho working in the farm; the way the old man touched the soil, almost fondling, and the way he tended the young tea plants as if they were his own [...] Ngotho was too much of a part of the farm to be separated from it [...] He could manage the farm labourers as no other person could" (waThiong'o 1964, 29-30).

Resistant youth characters are used to realize the theme of resistance in Harvest of Thorns. A character, Benjamin Tichafa, (the son of Mr Clopas Tichafa) who is portrayed as the novel's protagonist is an agent of change in the world of the novel. As a student, he and other students demonstrated against the colonial government's attempt to recruit male black school leavers into the military (exclusively reserved for whites) so as to use them (blacks) against their fellow blacks. He fought for Zimbabwe's independence, under Freedom Cliff, and remained instrumental in the actualization of his country's independence. His war name was PasiNemaSellout and his code number was $\mathrm{X}$-One-Five-Three-B. It is, however, unfortunate that his expectations (like that of his group) are cut off after independence. The role of the character, Msindo (an African servant) is also used to achieve the theme of resistance. It is demonstrated in the novel that Msindo is instrumental to the death of his master, Baas Mellecker. He is forcefully dragged out of his house and taken to the bush by some members of the freedom fighters. And through him Mellecker's four dogs are poisoned to death, and finally Mellecker is murdered by Mabunu Muchapera.

In the novel non-xenophobic and xenophobic characters are employed to highlight the theme of xenophobia. For instance, Benjamin and his wife (Nkazana) and his brother (Peter), are racially discriminated against by a white female trader in a supermarket. It is revealed that Benjamin, Nkazana and Peter while in the supermarket to buy groceries "the white girl sitting at the till" raises her eyebrows as she sees "them line up their three trolleys in front of her" (p.7). The white girl seems to look at them as inferior human beings who cannot afford anything in the supermarket. The grocer further shows her let-down on the trio by asking if they are sure of paying for all the collected groceries. It is important to point out that even though the grocer's Indian manager comes down from his glass office to settle the problem, the key point is that the whites have refused to show fairness and co-operation to blacks. "See what I mean? Benjamin fumed outside the shop. We've been so good to them they think they can still treat us as they used to!" (p.8). "They didn't learn anything from the war" (p.8). This theme of xenophobia is also realized through the belief of Benjamin. Benjamin is an ex-combatant male character who believes that things have not really changed as there still racial differences in the new independent African country. In this country, the whites, for instance, are still lords, while tending of lawns, pushing white babies in prams and the like are still "the only thing a black man can do" (p.40).

There is a portrayal of disappointed characters that make the theme of disappointment possible in the novel. The symbolic title, "Harvest of Thorns", indicates this theme of disappointment, suffered by characters that harvest thorns (failure and rejection) in the world of the novel. For example, Benjamin suffers disappointment. His failure to write O'level examinations affects him negatively soon after independence. He is denied the opportunity to enroll in the national army because he is not certificated. Ben's wife (Nkazana) and his new born baby boy are his only gain after independence. Ben's mother confirms Ben's reaping of failure when she tells him: "Look at your friends who finished school and started working. You'll never catch up with them (p.22). This statement of his mother demonstrates that she is very disappointed in him. It reveals Ben's frustration, poverty and irresponsibility. His mother further shows her disappointment in him, thus:

I don't know what it is I did in this world to deserve this. First you disappear from home. Then your father packs up. Then your sister runs off with a man I haven't seen. Now you come back to tear apart the little I have tried to hold together. You, who have brought me nothing but misery, finding fault with me! You want Peter to be a wreck too (p.21).

From the above cited excerpt, it is also shown that the husband of Ben's mother disappoints her by having an extra-conjugal affair with another woman, and the daughter, Esther, disappoints her by running away with a man, Dickson. Ben is used to reveal a society consisting of those who reap good fruits and those who harvest thorns. But unfortunately the family of Tichafa (Ben's family) belongs to the reapers of thorns. In Ben's words, "just because things have gone wrong in this family doesn't mean I wasted my life. There are millions in this country who are having it good because we went out. You just don't happen to be one of them" (p.22). Even though Ben's return from the bush war brought happiness, reconciliation and re-union to his father's family, there are more echoes of disappointments experienced by his mother and him. For instance, Ben disappoints his mother, Mrs Tichafa, by violating the African marriage culture, which says that before a woman and a man live as husband and wife, the 
consent of the two families must be sought for approval. Mrs Tichafa is disappointed in Ben for allowing Nkazana (Ben's wife) to come and stay with him (Ben) and be pregnant for him (Ben) without satisfying both families. Again, Ben disappoints his mother by staying outside their house for too long, only to return home drunk and sick. Even to his father, he is a disappointment as he exhibits a queer character, which negates his schooling. Instead of bringing happiness he brings sorrow, especially to her mother. Hence, he could be seen as a symbol of sadness in the novel.

In Harvest of Thorns student characters are used to depict the theme of corruption. These student characters are either portrayed as being corrupt or hypocritical or trickery. For instance, Chemhere is corrupt. Chemhere, a nickname of the leader of extortionists in Form Two leads his classmates into extorting Benjamin (a Form One student) of his groceries. He is equally portrayed as a bully and also as a bread-cutter (he shares bread for students who buy bread and margarine together). Mbombo, the epileptic, also, is portrayed as a hypocrite. Regardless of the fact that he rescues Benjamin from the hands of the chief extortionist, Chemhere, he is known for "receiving strange sad telegram from home" (p.91). He is "accused of having an affair with the old woman who bartered shoe-polish and tinfuls of salted peanuts for the students' weekly ration of blue soap" (p.91). As the vice-president of the Scripture Union, he desperately staves off his affliction with religion. It is demonstrated that he kept the dorm noisy one night while fighting Chemhere over the allegation of sleeping with an old woman. The allegation of sexual immorality and the neglecting of religious faith and resorting to fighting are marks of corruption and betrayal on the part of the mission school students. Another instance of a student used to realize the theme of corruption is Kainos (the football team's scoring machine). He is portrayed as a corrupt student who is "hopelessly in love at [age] fifteen" (p.91). It is indicated that he is always discussing how he sleeps with his girl friend, "rolling on a long stretch of carpet". It is also revealed that he is suspended from school for being found in the girls' dorm at night, trying to visit his girl friend" (p.91). From the foregoing, it can easily be said that Kainos is portrayed in the image of an archetypal Lothario- a male character who makes love to many women in The Fair Penitent, a play by Nicholas Rowe (1674-1718). As a student, also, Tawanda tricks his parents in the village by writing letters to them "to send more money for photosynthesis". He is not only shown for his crookedness and lies but also known for his familiarity with indecent and licentious words. It is revealed that he is argumentative and likes holding a discussion on masturbation "after lights out" (p.91). Chorosi is also another example of a corrupt student character used to achieve the theme of corruption. His being described as "green-fingered and yellow-toothed" suggests that he is naturally corrupt. Morally, he is unsound, because it is said that he takes pride "in showing off a bottle of Vaseline filled with three months of sperm" (p.91), which seems to be made through masturbation. This "Masturbation - talked about, imagined and practiced - was major dorm preoccupation, probably taking up as much time as the official school curriculum together" (p.91). It is also revealed that:

Often when lights went out Benjamin lay smelling the dorm stench of boy-flesh and sleep and occasionally urine, listening to the sporadic squeak of bed springs and the invariable soft gasp and sigh followed by rolling (pp.91-92).

In this school setting, Chinodya exposes the unimaginable corruption seen in the mission school. Through Benjamin we are told that "nobody takes praying seriously, not even the fathers. Nobody speaks to God at all. They believe too much in confession and not in fellowship. There is very little control over the boys and girls. They even make us drink wine at Mass. There are discos, film shows. There are too many temptations" (p.93). It is unfortunate that Benjamin's awareness of the meanings of masturbation and sex begins when a student shows him "pictures from a magazine, full-page pictures splashed with the gaping red flesh and hair of naked white men and women eating each other" (p.92).

His dorm-mates obsession with it and his pandering to those pictures completely shattered him at first. Whenever he remembered the boys swarming over him, pulling away his bedclothes and laughing at his boyhood, his heart beat quickly, filling him with the sudden strange anxiety to grow up. He had never imagined children of church-going people, at a mission school for that matter, could behave as his dorm-mates did, swearing, lying, smoking, drinking and cheating through their sordid little lives (p.92).

What Chinodya seems to be emphasizing here is that the effect of literature on the reader or audience or spectator is uncontestable. Literature can mar or make a person; hence a person should be mindful of the kind of literature he/she patronizes.

\section{Diction as a Vehicle of Meaning}

Chinodya's choice of diction in Harvest of Thorns brings out the aesthetic quality, the themes, and desirability of this novel. In reading Harvest of Thorns, one is quickly reminded of Jean-Paul Sartre's postulation- that "one is not a writer for having chosen to say certain things, but for having chosen them in a certain way. And to be sure, the style 
makes the value of the prose" (Sartre, 1950, p.15). The dynamism in Chinodya's use of language lies hugely in his handling of different linguistic elements in the description of incidents and situations. For instance, after Benjamin accidentally hacks Peter's one leg in the course of splitting blocks of wood, it is demonstrated that Peter is taken to hospital. As Peter is in the hospital, it is reported that:

The Overseer had prayed at the bed. Mr Chikwa had prayed. Mrs Pondokazi had prayed. Oswell's father had prayed. Maria's aunt had prayed [...] The church people had sung and prayed (p.85).

What is found in the above passage and in the illustration table below is repetition:

\begin{tabular}{l|l|l}
\hline The Overseer & & \\
Mr Chikwa & Had & + prayed \\
Mrs Pondokazi & & \\
Oswell's father & & sung and prayed \\
Maria's aunt & \\
The church people & & \\
\hline
\end{tabular}

It is pure linguistic foregrounding because the use of a simple expression: "The church people" plus (+) "had prayed" would serve the same purpose in the normal English language code. But the use of repetition here is for rhetorical emphasis, drawing attention to the reader's mind the message effect- that the Church of the Holy Spirit is a prayerful church and serves as a means of taming the African people, so that they do not get provoked to anger. In other words, the church serves as an anti-revolutionary institution of the oppressor. In another way, the church here is an ideological agency of oppression.

There is the use of foregrounding imagery which draw attention to themselves. This is evident in the following excerpt:

Our church has no label, the man said with a flourish. We are not the Roman Catholic Church or the Anglican Church or the Assemblies of God or the Lutheran Church or the Methodist Church or the Dutch Reformed Church or the Church of Sweden or the Presbyterian Church or the Church of Christ or the Apostolic Faith Mission but God's Church. We are the Church of the Holy Spirit and we worship God directly (p.61).

Apart from the Church of the Holy Spirit, every other Church is created in the image of a bird of prey- be it a hawk or a vulture or an owl. Chinodya uses all the parallel denominations, beginning from the Roman Catholic Church to the Apostolic Faith Mission, to explore similar features of man's deception and exploitation by his fellow man. The Church serves as a canopy wherein men hide to deceive, exploit and oppress their fellow men.

In Harvest of Thorns African oral performance is used to draw attention to the story of the advent of colonialism and its aftermath in Rhodesia (now Zimbabwe). For instance, the introductory formulae used at the beginning of this story of the white man's arrival and the consequences of his arrival in Zimbabwe are so significant that they integrate the audience/readers into the storytelling process. The formulae openings are presented thus:

'Icho!'Baas Die chants.

'Charira!'the crowd shouts back

'Icho!'

'Pamberi ne Chimurenga!'

'Pamberi!'

'Ndichambokuitirai ngano yangu', Baas Die says, I'm going to tell you a little story' (p.153).

In this scene, it is Baas Die (the resistant group leader) who leads while the other revolutionary agitators follow gradually until they are moved to the story proper. This movement serves as a mind-bender; and it is "necessary for effective suspension of disbelief" (Chukwuma, 2002, p.228). Through this unscripted performance Chinodya is able to have the reader see the reality of the colonialists' exploitative and oppressive character in the world of the novel.

Chinodya employs flashback in his narrative in order to bring to the forefront the ugly experience of Zimbabweans in the nineteen-sixties and to project the way forward for the country. By using flashback in this text we are meant to understand that the knowledge of our history helps to advance our future. For instance, in the bush scene, historical/political discussions are held among the freedom fighters. These historical/political discussions expose the 
ugly state of the nation right from the inception of colonialism. Issues of capitalism, socialism, democracy, xenophobia, injustice and justice, and the Land Apportionment Act, and oppression and exploitation, and neocolonialism are heard. In addition, the chasm between white race and black race is presented. This is seen in what the freedom fighters are told. They are told that:

Five percent of the population owned the better half of Rhodesia and earned more than the ninety-five percent together, that they had the best jobs, homes, schools, hospitals - everything - because their skin was lighter than yours (p.115).

By introducing this flashback into his story Chinodya brings to the forefront the social inequality in the Zimbabwean society during the colonial period. Besides, it is used to paint the picture of xenophobia existing in the same colonial time.

Again, through flashback the reader is presented with the past corrupt lifestyle of a colonialist's loyalist character (Mr Tichafa). MrTichafa is portrayed as a religious zealot; and his religious zealotry is inculcated into the life of every member of his family- from wife to children. However, he hides under the umbrella of the church to resist political change in the country. He seems to be unconscious of the fact that his church - the Church of the Holy Spirit - serves as an anti-revolutionary institution. This is reflected in Mr Tichafa's refusal to belong to a political party because of his affiliation with the Church of the Holy Spirit. He says: "We're church people. We're interested in the spirit, not in the flesh. If it is God's will to change a government, then He will change it Himself in His own time" (p.75). In this instance, for Mr Tichafa, going into revolutionary politics would mean working against the social status quo which he and other church members uphold. The meaning of this is that while Mr Tichafa and his church members uphold the social status quo, he uses biblical allusion to dismiss any calls for social change. Mr Tichafa's confession about his past reads thus:

Before He found me I did anything for money. I lied, I cheated, I stole. I lurked in the bushes behind houses and robbed the drunk and the old. I gambled at cards with men like me who did not care about losing their salary if it could bring them more, and if I didn't win I slashed my rivals with knives and cast them into ditches. Yes, I killed for money (p.74).

Despite Tichafa's confession, still there is no real change in him. This is because both Tichafa and the Overseer of the Church of the Holy Spirit are victims of corruption. While "the Overseer" steals "church money", Tichafa "is having an affair with the woman next door" (p.95).

Through flashback the role played by the ancestors of the land are laid bare so as to affirm that colonialism came with oppression and exploitation. It is indicated that the children's children of Chamunika and Nehanda had been under the enslavement of the white men "so long ago that three generations of that offspring had left the country to seek work on the farms, in the houses and towns of the white men who had taken their land" (p.135). This means that the white man came to Rhodesia and drove the aborigines of Rhodesia out of their land and forced them to go and live in the hills where the land was not fertile. Subsequently the masses are compelled to work "in the strangers' fields and gardens and home" (p.161). To consolidate their dominance over the villagers, "they made new rules", thus:

The villagers' wives had to be counted. Their children had to be counted. The marks on their bodies had to be counted. Their cattle and goats and sheep had to be counted. No villager could hunt without the strangers' permission. No villager could chop down a tree without permission. No villager could cut a roll of grass without permission. No villager could build a hut without permission. No villager could marry without permission (pp.161-162).

Apart from introducing new rules for the people of Rhodesia, the foreigners also stripe Rhodesians of their cultural identity. However, the promise of Svikiro (the goddess of the land) that the foreigners will go once the throat of their children are cut fails as the foreigners overheard it and "took the Svikiro away and hanged her" (p.162). As soon as the villagers were disconnected from their source of strength and motivation they could not chase out the strangers again. Rather the villagers became the strangers' slaves.

There is the use of contrastive juxtapositions in the portrayal of the dwelling place of the whites vis-à-vis that of the blacks to accentuate the degrees of social inequality in the world of the novel. Whereas the white minority ruling class or the colonial masters inhabit the best and largest of the African people's land by force,

the villagers stayed on the hills. They built new huts there, but the land was steep and barren. There was not enough land to plough or enough pasture for their livestock. They have lost their land and their livestock to the strangers. They could no longer grow vegetables in the valley. They could no longer fish in the river. 
They could no longer collect fire wood or logs or grass in the forest. They could no longer hunt (p.161).

Furthermore, in Harvest of Thorns a direct and a more dramatic use of uninterrupted dialogue between characters as usually seen in plays are delineated. Through dialogue between characters most of the themes in the novel are uncovered. For example, the dialogue between a soldier and Benjamin speaks volume of the military cruelty (pp.102-104). Also, the conversation between Mr and Mrs Tichafa on the issue of a battered red car, Zephyr Zodiac, bought from a German at his departure by Mr Tichafa at the cost of six hundred dollars, with the gift of a dog Dingo -is used to reveal the betrayal and oppressive complexion of Mr Tichafa. It is indicated that the Zephyr Zodiac car "wouldn't start. It sputtered, grumbled, hummed but it wouldn't start" (p.236). The car poses a burden instead of comfort. The car refuses to be useful as he (Tichafa) fails to be useful to his family (because he abandons his family and has a child outside wedlock). As regards the dog, dingo, it symbolizes deprivation and oppression. This is because the milk which should have been consumed by the family of Mr Tichafa is served dingo, instead. Dingo's barking and growling make it difficult for the family members of Mr Tichafa to relate very well. Dingo tears Peter's shorts- indicating oppression. It is only Mr Tichafa who has control over dingo. Dingo, here, is like the police and the army that are used by the white minority ruling class to oppress the black people of Zimbabwe.

\section{Conclusion}

Chinodya's Harvest of Thorns x-rays the problems of colonialism and neo-colonialism in Zimbabwe. Through the novelistic tools -characterization and diction- the author features the cause and effect of colonialism and neocolonialism in Zimbabwe as he perceives it. This implies that the beauty of literature lies in its literary elements. The study demonstrated that the novelistic elements -character, linguistic foregrounding, unscripted performance, foregrounding imagery, flashback, juxtaposition and dialogue - employed by the author have positively contributed to the development of the themes of the novel. In other words, the author achieves his themes of oppression, exploitation, corruption, resistance, disappointment, xenophobia and social disparity through the above mentioned techniques deployed.

\section{References}

Brooks, C. (ed.) (1963). The Formalist Criticism. A Short History of Literary Criticism. (pp.174-185), Vemon Hall: New York University Press.

Chinodya, S. (1990). Harvest of Thorns. Essex: Heinemann.

Chukwuma, H. (2002). Igbo Oral Literature: Theory and Tradition. $2^{\text {nd }}$ ed. Port Harcourt: Pearl Publishers.

Dzimbanhete, J. A. (2019). Drawing Lessons from Zimbabwe's War of Liberation: Efficacious Use of Propaganda and $\quad$ Violence. $\quad$ Retrieved from smallwarsjournal.com/jrnl/art/drawing-lessons-from-zimbabwe's-war-of-liberation/

Ngara, E. (1985). Art and Ideology in the African Novel. London: Heinemann.

Nnolim, C. (ed.) (1999). Introduction. Approaches to the African Novel: Essays in Analysis. $2^{\text {nd }}$ ed. (pp.7-15), Owerri: Ihem Davis Press.

Sartre, J. (1950). What is Literature? Trans. Bernard Fretchtman. London: Methuen \& Co.

Schorer, M. (1966). Technique as Discovery. In Robert Scholes (ed.) Approaches to the Novel. (pp. 141-160), Scraton: Chandler Publishing Company.

Scott, W. S. (1962). Five Approaches of Literary Criticism. New York: Collier Books.

Staunton, I. (1997). The Seventeen-Year Civil War and Its Immediate Literary Aftermath. The Literature and Culture of Zimbabwe. (pp. 1-11), Harare: Baobab Books.

Vazquez, A. (1973). Art and Society: Essays in Marxist Aesthetics. London: Melvin Press.

Wa Thiong'o, N. (1964). Weep Not, Child. London: Heinemann. 